\title{
Hubungan Dukungan Keluarga Dengan Tingkat Kehilangan Pada Pasien Hiv/Aids Di Poliklinik Care Support And Treatment (Cst) Rsud Kabupaten Batang
}

\author{
Rini Sari ${ }^{1}$ \\ 1. STIKes Karya Husada Semarang \\ Email: rini.sari@gmail.com
}

\begin{abstract}
Abstrak
Data statistik kasus HIV/AIDS di Indonesia sampai bulan September 2014 orang yang meninggal akibat HIV/AIDS sebanyak 9.796 orang. HIV/AIDS tidak hanya memberikan dampak psikologis yang besar bagi penderitanya. Pasien HIV/AIDS perubahan karakter psikososial yaitu : hidup dalam stres, depresi, merasa kurangnya dukungan sosial, dan perubahan perilaku. Tujuan penelitia ini untuk mengetahui hubungan dukungan keluarga dengan tingkat kehilangan pada pasien HIV/AIDS di Poliklinik Care Support and Treatment (CST) RSUD Kabupaten Batang. Metode : desain penelitian menggunakan deskriptif korelasi dengan pendekatan cross sectional. Sampel penelitian adalah pasien HIV/IDS di poliklinik CST RSUD Kabupaten Batang sebanyak 50 orang. Pengambilan sampel menggunakan total sampling. Instrumen penelitian adalah kuesioner. Analisa data menggunakan uji chi square. Hasil penelitian dengan analisa univariat diperoleh $86 \%$ responden mendapatkan dukungan keluarga yang cukup dan $60 \%$ responden melalui tingkat kehilangan yang cukup. Analisa bivariat dengan chi square diperoleh $\rho$ value $0,006<0,05$. Kesimpulan penelitian ini ada hubungan dukungan keluarga dengan tingkat kehilangan pada pasien HIV/AIDS di Poliklinik Care Support and Treatment (CST) RSUD Kabupaten Batang. Saran untuk perawat adalah dapat memberikan asuhan keperawatan pada pasien HIV/AIDS dengan melibatkan keluarga dalam pemberian konseling pada pasien HIV/AIDS sehingga keluarga dapat mengetahui pentingnya manfaat dukungan keluarga pada pasien HIV/AIDS.
\end{abstract}

Kata Kunci: Dukungan keluarga; Tingkat Kehilangan; HIV/ AIDS

\section{Pendahuluan}

Salah satu masalah kesehatan yang menjadi isu penting bersama masyarakat dunia adalah penyakit AIDS yang disebabkan oleh HIV. Berdasarkan data statistik kasus HIV/AIDS di Indonesia sampai bulan September 2014 orang yang meninggal akibat HIV/AIDS sebanyak 9.796 orang. Propinsi Jawa Tengah sampai September 2014 menempati tempat ke empat dengan jumlah penderita HIV sebanyak 13.507 orang dan AIDS sebanyak 4.191 orang (Spiritia, 2015). Di Kabupaten Batang terdapat 681 ODHA, jumlah tersebut kumulatif dari tahun 
2007 sampai bulan Desember 2015 ( DKK Batang, 2016).

Orang-orang dengan HIV-AIDS atau ODHA mengalami berbagai masalah kesehatan, baik fisik maupun psikologis, akibat infeksi HIV-AIDS tersebut. Diagnosis HIV dan AIDS dapat berdampak pada aspek psikologis dan menimbulkan berbagai masalah, baik dengan penerimaan status diri sebagai seseorang yang positif HIV maupun penerimaan orang terdekat atas status positif HIV tersebut (Gabriella, 2015)

Kelelahan secara historis telah menjadi masalah umum di antara orang yang hidup dengan HIV, dengan tingkat prevalensi mendekati $90 \%$. Faktor yang menyebabkan kelelahan yaitu gangguan depresi khususnya gangguan psikologis dan kecemasan (Spiritia, 2010).

Dukungan sosial sangat diperlukan terutama pada pasien HIV yang sudah sangat parah. Individu yang termasuk dalam memberikan dukungan sosial meliputi pasangan (suami/ istri), orang tua, anak, sanak keluarga, teman, tim kesehatan, atasan dan konselor (Nursalam \& Kurniawati, 2007:28).

Stuart dan Sundeen (1998, dalam Tamheer \& Noorkasiani, 2009:8) menyatakan bahwa dukungan keluarga merupakan unsur terpenting dalam membantu individu menyelesaikan masalah kesehatan. Apabila ada dukungan, rasa percaya diri akan bertambah dan movitasi untuk menghadapi masalah kesehatan yang terjadi akan meningkat.

Rumusan masalah penelitian ini adalah "Apakah ada hubungan dukungan keluarga dengan tingkat kehilangan pada pasien HIV/AIDS di Poliklinik Care Support and

\section{Treatment (CST) RSUD Kabupaten Batang?}

Tujuan umum penelitian yaitu untuk mengetahui hubungan dukungan keluarga dengan tingkat kehilangan pada pasien HIV/AIDS di poliklinik Care Support and Treatment (CST) RSUD Kabupaten Batang.

\section{Metode Penelitian}

Penelitian ini bersifat deskriptif korelasi, dengan desain penelitian cross sectional. Populasi dalam penelitian ini adalah seluruh pasien HIV/AIDS di Poliklinik CST RSUD Kabupaten Batang sebanyak 50 orang.

Sampel dalam penelitian adalah pasien HIV/IDS di poliklinik CST RSUD Kabupaten Batang sebanyak 50 orang. Pengambilan sampel menggunakan total sampling (sampel jenuh) yaitu seluruh anggota populasi diambil sebagai sampel penelitian (Hidayat, 2007:34). Pengolahan 
data melalui langkah- langkah editing, scoring, coding, processing dan cleaning Notoatmodjo (2010, hh. 176-177).

\section{Hasil Penelitian Dan Pembahasan}

Hasil penelitian menunjukkan bahwa sebagian besar (86\%) responden mendapatkan dukungan keluarga yang cukup. Hasil penelitian menunjukkan bahwa sebagian besar (86\%) responden mendapatkan dukungan keluarga yang cukup. Dukungan keluarga yang cukup dapat dilihat dari distribusi frekuensi yaitu $90 \%$ responden menyatakan bahwa keluarga tetap memperlakukan pasien HIV/AIDS sebagai bagian dari keluarga dan $78 \%$ responden menyatakan bahwa keluarga mendoakan agar pasien HIV/AIDS segera mendapatkan kesehatan. Terdapat $72 \%$ responden yang menyatakan bahwa keluarga menerima pasien HIV/AIDS dengan iklas dan $72 \%$ responden menyatakan bahwa keluarga berperan aktif dalam pengobatan.

Peran keluarga sangat dibutuhkan dalam memelihara kesehatan pasien HIV/AIDS. Peran keluarga dapat diberikan dalam bentuk dukungan keluarga pada pasien HIV/AIDS. Menurut Friedmen (2010) peran keluarga sangat dibutuhkan untuk memelihara kesehatan anggota keluarganya yang sakit.

Pasien HIV/AIDS yang mendapatkan dukungan cukup disebabkan keluarga mengetahui dan memahami bahwa pemberian dukungan pada pasien HIV/AIDS oleh anggota keluarga seperti suami, istri, orang tua dan anak dapat membangkitkan semangat dalam menjalani pengobatan. Dukungan lebih efektif jika diberikan oleh orang terdekat seperti keluarga. Hal ini sesuai dengan Ratna (2010) yang menyatakan bahwa pemberian dukungan keluarga, lebih efektif dari orang- orang terdekat yang mempunyai arti dalam hidup individu.

\section{Tingkat Kehilangan pada Pasien HIV/AIDS}

Hasil penelitian menunjukkan bahwa sebagian besar $(60 \%)$ responden melalui tingkat kehilangan yang cukup. Tingkat kehilangan yang cukup dapat dilihat dari distribusi frekuensi yaitu $74 \%$ responden menyatakan bahwa akan melakukan apa saja buat keluarga seandainya dapat sehat seperti sebelum sakit dan $70 \%$ responden menyataan bahwa kesehatannya saat ini baik-baik saja. Pasien HIV/AIDS setelah didiagnosis menderita penyakit HIV/AIDS akan 
memberikan reaksi yang berbeda- beda sebagai bentuk adaptasi terhadap penyakit yang dideritanya. Pasien yang mendapatkan diagnosa bahwa dirinya menderita penyakit HIV/AIDS merupakan suatu pengalaman yang tidak menyenangkan yang berpotensi menimbulkan suatu reaksi stres, cemas dan sebagainya. Pasien setelah didiagnosis menderita HIV/ADIS akan memasuki suatu proses adaptasi baik secara fisik, psikologis dan sosial budaya. Salah satu dimensi dalam proses adaptasi adalah dimensi psikologis. Pasien HIV/AIDS harus dapat mengatasi perubahan dimensi psikologis yang ditandai dengan berubahnya sikap perilaku individu, oleh karena adanya upaya yang terus menerus dilakukan setelah didiagnosis HIV/AIDS seperti penyangkalan, marah, depresi hingga tahap menerima.

\section{Hubungan Dukungan Keluarga Dengan Tingkat Kehilangan pada Pasien HIV/AIDS}

Hasil penelitian ini menunjukkan bahwa dukungan keluarga yang baik pada pasien HIV/AIDS dapat membantu pasien untuk berdaptasi dan menjalani proses tahap kehilangan dengan adaptif.

Dukungan keluarga ini sangat dibutuhkan oleh pasien HIV/AIDS untuk mengatasi masalah kesehatan yang sedang dihadapinya. Pasien HIV/AIDS yang mendapatkan dukungan yang baik dapat mengelola penyakit dan masalah psikologis yang dialaminya dengan baik. Hal ini sesuai dengan Pudjiastuti \& Utomo (2003) menyatakan bahwa dukungan sosial terutama keluarga dan cara mengatasi masalah merupakan mediator dalam mengatasi penyakit yang berhubungan dengan stres. Responden yang mendapatkan dukungan kurang dapat disebabkan keluarga kurang memahami pentingnya dukungan keluarga bagi pasien dalam menghadapi penyakitnya. Effendi dan Makhfudli (2009) menyatakan bahwa dukungan keluarga sangat diperlukan oleh setiap individu di dalam setiap siklus kehidupannya.

Dukungan keluarga dibutuhkan oleh pasien HIV/AIDS dalam mengatasi dampak psikologis setelah pasien terdiagnosa menderita HIV/AIDS.

\section{Kesimpulan}

Karakteristik responden diketahui 54\% responden berusia 35-47 tahun, 62\% responden berjenis kelamin perempuan, 64\% responden berpendidikan dasar, 50\% responden berdasarkan lama menderita berusia 44-59 bulan. Dukungan keluarga menunjukkan bahwa 86\% responden mendapatkan dukungan keluarga yang cukup dan Tingkat kehilangan menunjukkan bahwa $60 \%$ responden melalui tingkat kehilangan yang cukup. Ada hubungan dukungan keluarga dengan 
tingkat kehilangan pada pasien HIV/AIDS di Poliklinik Care Support and Treatment (CST) RSUD Kabupaten Batang dengan $\rho$ value $0,006<0,05$.

\section{Saran}

Bagi Keluarga dari Pasien HIV/AIDS Keluarga pasien HIV/AIDS disarankan untuk lebih memperhatikan anggota keluarga yang menderita sakit HIV/AIDS dengan menanyakan keadaan pasien jika pasien terlihat tidak sehat. Perawat dapat memberikan asuhan keperawatan pada pasien HIV/AIDS dengan melibatkan keluarga dalam pemberian konseling pada pasien HIV/AIDS sehingga keluarga dapat mengetahui pentingnya manfaat dukungan keluarga pada pasien HIV/AIDS.

\section{Daftar Pustaka}

Gabriella. (2015). Kebutuhan Layanan Psikologis dan Kesehatan Jiwa Dalam Penganggulangan HIV dan AIDS. http:// http://www.kebijakanaidsindonesia.net/i

Notoatmodjo, 2012, Metodologi Penelitian Kesehatan, Penerbit Rineka Cipta, Jakarta

Triwibowo. (2013). Hubungan Dukungan Keluarga Dengan Respon Berduka Pada Klien Kanker Di Rumah Sakit Islam Sakinah Mojokerto. STIKES PPNI Bina Sehat. Mojokerto

WHO. (2015). $\quad$ HIV/AIDS. http://www.who.int/mediacentre 